\title{
Jaraqui's Pate: Centesimal Evaluation
}

DOI: $10.46932 /$ sfjdv1n4-002

Received in: August 1st, 2020

Accepted in: September 30th, 2020

\section{Edson Francisco do Espírito Santo}

Doutor em Ciência Animal pela Universidade Estadual Paulista "Júlio de Mesquita Filho" Instituição: Instituto Federal de Educação, Ciência e Tecnologia do Estado do Amazonas (IFAM), Campus Manaus Zona Leste (CMZL)

Endereço: Avenida Cosme Ferreira, no . 8.045, Bairro: São José Operário, Manaus/AM

E-mail: edson.santo@ifam.edu.br

\section{Julia Eudoxia Decaris Rolim}

Graduada em Medicina Veterinária

Instituição: Instituto Federal de Educação, Ciência e Tecnologia do Estado do Amazonas (IFAM),

Campus Manaus Zona Leste (CMZL)

Endereço: Avenida Cosme Ferreira, nº. 8.045, Bairro: São José Operário, Manaus/AM

E-mail: juliaeudoxia@ hotmail.com

\section{Ytaiara Lima Pereira}

Graduanda em Medicina Veterinária

Instituição: Instituto Federal de Educação, Ciência e Tecnologia do Estado do Amazonas (IFAM),

Campus Manaus Zona Leste (CMZL)

Endereço: Avenida Cosme Ferreira, nº. 8.045, Bairro: São José Operário, Manaus/AM

E-mail: ytaiaralima@gmail.com

\section{Flávia de Carvalho Paiva Dias}

Mestra em Ciência de Alimentos pela Universidade Federal do Amazonas (UFAM) Instituição: Instituto Federal de Educação, Ciência e Tecnologia do Estado do Amazonas (IFAM), Campus Manaus Zona Leste (CMZL)

Endereço: Avenida Cosme Ferreira, nº 8.045, Bairro: São José Operário, Manaus/AM

E-mail: flavia.dias@ifam.edu.br

\author{
Washington Clementino Amorim Júnior \\ Tecnólogo em Gastronomia pela Faculdade Metropolitana de Manaus \\ Instituição: Instituto Mix de Profissões \\ Endereço: Avenida Torquato Tapajós, no . 1.947, Bairro: Flores, Manaus/AM \\ E-mail: was.junior@gmail.com
}

\begin{abstract}
This work aimed to elaborate two formulations of jaraqui pate, the pasty and the creamy, and to carry out the physical-chemical analysis of the products. Initially, mayonnaise was made and then the raw materials were added. For pasty, 30.28\% of cooked jaraqui fillet, $0.14 \%$ of curing salt and $69.56 \%$ of mayonnaise were used. For the creamy, $15.19 \%$ of cooked jaraqui fillet, $15.19 \%$ of raw jaraqui fillet, $0.14 \%$ of curing salt and $69.45 \%$ of mayonnaise. After elaboration, the physical-chemical analysis was performed. The $\mathrm{pH}$ of the samples (6.0) showed no difference between the products. The pasty and creamy pates showed values of humidity, ash, lipids, proteins and carbohydrates, respectively:
\end{abstract}


$56.32 \%, 1.1 \%, 23.33 \%, 10.92 \%$ and $8.32 \%$; and $57.03 \%, 1.5 \%, 23.04 \%, 9.02 \%$ and $9.34 \%$. Only the values of humidity and ash showed a significant difference $(\mathrm{p}<0.05)$. Both formulations fit the current legislation for physical-chemical analysis.

Keyword: Chemical physical analysis, fish pate, derivative products, Semaprochilodus spp, fish technology.

\section{INTRODUCTION}

Fish are the main source of animal protein for the population of the northern region of Brazil. These products contain high biological value and the protein amount can be compared to that of other animal products, such as beef (PEREIRA; FONSECA, 2011). The aforementioned region has a higher consumption of fish, compared to other regions of the country; as an example, Amazonas that presents an average annual consumption of $35 \mathrm{~kg} /$ person, a value well above the average of national consumption, which is $14.5 \mathrm{~kg} /$ person / year (BRAZIL, 2014). The fishing sector of this state produces about 150,000 t / year, of which, of this total, fishing represents 80,000t, highlighting the socioeconomic and cultural importance of this activity for the region, since it is one of the sources of income (INFOPESCA, 2010; SOUSA, 2014; ISAAC et al., 2015).

Jaraqui is one of the most popular fish in the North region, where it represents about $70 \%$ of the species' production in the Manaus market (SANTOS et al., 2006), being a fish originating from large volumes of fishing, but considered low commercial value. It is among the most consumed and commercialized fish in Amazonas (BARTHEM; FABRÉ, 2004; BEGOSSI et al., 2019), and has relevant commercial interest in the fish production chain in the region, being the fourth most caught fish on the Madeira, RO river basin in 2004 , with a volume of $39,750 \mathrm{~kg}$ or $8.64 \%$ of the total extracted (DORIA et al., 2012 ).

It is noteworthy that the jaraqui fishing is still, in short, extractive, which generates a greater offer than the demand, with the fish sometimes being discarded, with a clear need for new ways of using and improving it (MACHADO et al., 2020).

Among meat emulsions, pâté represents a product with sensory properties that are widely appreciated throughout the world, having an extensive gastronomic history, evolving from goose liver pâté ("foie-grass") to recent fish formulations (SCHMELZER-NAGEL, 1999; ECHARTE et al., 2004; VOSSEN et al., 2012). It is defined as an industrialized meat product obtained from meat, meat products and / or edible offal, which can be of different animal species and transformed into paste, adding ingredients and subjected to an appropriate thermal process (BRAZIL, 2017). 
The inclusion of different types of raw materials in the formulation of pates, expands the variety available on the market, allowing different sensory characteristics for the consumer and better use of the nutritional advantages of different meats, including fish. Fish pates have a high added value, increasing income and generating direct and indirect jobs, being a great alternative for increasing production in industries, cooperatives and the fishing community, including Amazonas, as they present high rates of fish consumption. by the population (MINOZZO, 2005).

The quantitative knowledge of the chemical composition of the meat of the different species of fish is essential for the elaboration of correctly balanced diets, such as in the use of fish processing. These values can affect the type of processing method used in addition to the product's flavor, texture and stability (SALES; SALES, 1990).

The Technical Regulation on Pate Identity and Quality established by the Ministry of Agriculture sets the identity and the minimum quality characteristics that pates must present (BRASIL, 2000). In addition, during the period of preparation of the product, the manufacturers must pay attention to the required legislation, as stated in ordinances No. 1002 and 1004 of December 11, 1998, in order to guarantee the quality of the food, stability emulsion and avoid contamination by microorganisms harmful to health.

The objective of this work was to prepare pasty and creamy pâtés and to carry out their physicalchemical evaluation, with analyzes of moisture, ashes, lipids and proteins. As pates are derived products that are easy to prepare and inexpensive, they are considered excellent ways to enhance raw materials. The use of jaraqui, a popular Amazonian fish, was intended to add value to this meat, given the market appeal of the region, thus demonstrating the viability of its use at commercial levels, reinforced by the findings of Machado et al. (2020), since the fillets of the species obtained more than $60 \%$ of consumption intention in their study.

\section{MATERIAL AND METHODS}

\subsection{SAMPLING}

The samples of fresh fish were acquired from an open market in the city of Manaus - AM, and were filleted in the laboratory. From the fairs, 6 samples were acquired for the preparation of pasty and creamy pates. The ingredients used in the formulation were purchased from local stores. 


\subsection{ELABORATION OF THE PRODUCT}

Two pate recipes were made with a total of $800 \mathrm{~g}$ each, following the proportion of $70 \%$ mayonnaise and $30 \%$ jaraqui fillet. The first - pasty pate - contained 30\% cooked fillet. The second creamy pate - contained $15 \%$ cooked fillet and $15 \%$ raw fillet.

The fillets were crushed in a multiprocessor and later added to the mayonnaise. The following ingredients were used to prepare mayonnaise: boiled egg (39.95\%), powdered milk (5.27\%), vinegar $(3.59 \%)$, oregano $(0.18 \%)$, refined salt $(1,09 \%)$, soybean oil $(18.45 \%)$, chives $(0.96 \%)$, garlic $(0.3 \%)$, parsley $(0.1 \%)$ and curing salt $(0.15 \%)$. After the homogenization of the pâté pastes, a thermal treatment was carried out, where the products remained at $80{ }^{\circ} \mathrm{C}$ for $35 \mathrm{~min}$ in a water bath and then cooled in a water and ice bath.

\subsection{POTENTIOMETRIC DETERMINATION OF PH}

Ten grams of crushed samples from the pates were diluted in $100 \mathrm{~mL}$ of water for the potentiometric determination of $\mathrm{pH}$, according to the Analytical Standards of the Adolfo Lutz Institute (2008).

\subsection{ANALYSIS OF THE PHYSICAL-CHEMICAL COMPOSITION}

In the jaraqui pates the values of humidity, proteins, lipids and ash were determined according to AOAC (2000). The total carbohydrate content (\% Ca) of the samples was calculated using the difference method.

$$
\% C a=100-(\% U+\% L+\% P+\% C i)
$$

Where: $\% \mathrm{Ca}=$ percentage of carbohydrates; $\% \mathrm{U}=$ percentage of humidity; $\%$ PARA $=$ percentage of proteins; $\% \mathrm{~L}=$ percentage of lipids; $\% \mathrm{Ci}=$ percentage of ash.

\subsection{STATISTICAL ANALYSIS}

The results obtained were subjected to analysis of variance and the means compared by the Tukey test, with a significance level of 5\%, using the Minitab statistical program, version 16.0.

\section{RESULTS AND DISCUSSION}

The physicochemical composition of the Jaraqui pates is shown in Table 1. 
Table 1. Physicochemical composition of pasty and creamy jaraqui pates (Semaprochilodus spp.)

\begin{tabular}{cccccc}
\hline & Humidity & Ashes & Lipids & Proteins & Carbohydrates \\
& & & & & \\
\hline Pasty pate & $56,32 \% \pm 0,14 \mathrm{~B}$ & $1,10 \% \pm 0,01$ & $23,33 \% \pm 0,27 \mathrm{~A}$ & $10,93 \% \pm$ & $8,32 \% \pm 0,53 \mathrm{~A}$ \\
& & $\mathrm{~B}$ & & $0,70 \mathrm{~A}$ & \\
Creamy pate & $57,03 \% \pm 0,09 \mathrm{~A}$ & $1,51 \% \pm 0,03$ & $23,04 \% \pm 0,22 \mathrm{~A}$ & $9,02 \% \pm 0,54$ & $9,34 \% \pm 0,23 \mathrm{~A}$
\end{tabular}

Data refer to mean \pm error. Averages followed by equal letters in the column, do not differ from the Tukey test ( $\mathrm{p}>0,05)$.

Among the samples analyzed, it was found that the moisture and ash determinations were statistically different from each other $(\mathrm{p}<0.05)$ and the lipids, proteins and carbohydrates determinations did not show any significant difference ( $\mathrm{p}>0.05)$.

The technical regulation of identity and quality of pate established by the Ministry of Agriculture establishes the identity and the minimum quality characteristics that this meat product must present, where the maximum total moisture and fat are $70 \%$ and $32 \%$, respectively, and for proteins the established minimum is $8 \%$ (BRASIL, 2000). The two formulations of jaraqui pate, proposed in this work, fit the legislation currently in force with respect to the aforementioned determinations. The measured $\mathrm{pH}$ value did not vary between samples, remaining constant at 6.0 and within the parameters established by the Sanitary Norms of the Adolf Lutz Institute (2008), which consider that the pH of the pate should be slightly acidic.

Minozzo (2005) reported moisture, ash, lipid and protein contents for tilapia pate in quantities: $59.47 \%, 2.20 \%, 27.41 \%$ and $8.53 \%$, respectively. The values found in the present study were lower when compared to the aforementioned study, with the exception of proteins that were higher. It is understood that all fish species have similar protein values, and that this value is inversely proportional to the fat and water content (OGAWA, 1999).

Echart et al. (2004) and Aquerreta et al. (2002) obtained values for lipids in salmon, anchovy, cod, tuna, salmon and anchovy pates of $26.39 \%, 16.10 \%, 13.72 \%, 10.01 \%, 28.90 \%$ and $26.16 \%$, respectively. Minozzo et al. (2008) obtained lipid values for pasty and creamy tilapia pates of $26.12 \%$ and $28.15 \%$, respectively. The values found in the present study, $23.33 \%$ and $23.03 \%$ for the pasty and creamy pates, were closer to the values found by Minozzo et al. (2008), but smaller. This is justified by the lower percentage of fish meat used in the formulations compared to the aforementioned study.

Variations in lipid values occur due to the different formulations used, since some ingredients have a higher fat content than others. Likewise, the species of fish used in the preparation directly influences the lipid content, since this item is one of the most varied in the composition of fish. 
Carbohydrate values were as expected, a fact that can be explained by the use of mayonnaise, which has several components rich in carbohydrates. The values did not differ statistically $(p>0.05)$ because the same formulation of mayonnaise was used in both samples, in addition to the percentages added being equivalent.

The mineral values found demonstrate that these products can be considered as sources of essential minerals for the human organism.

\section{CONCLUSION}

In the present study, it can be concluded that the values found for the physical-chemical analysis of the pasty and creamy jaraqui pates were found within the values established within the identity and quality standards of the general pate legislation.

The use of jaraqui, an Amazonian species that is little explored in the processing of food, has real viability, since the products fall under the legislation. It is also inferred that other little-explored Amazonian species also have potential for use in different types of processing, which demonstrates the enormous potential of the region in the area of fish technology.

\section{REFERENCES}

AQUERRETA, Y.; ASTIASARÁM, I.; MOHINO, A.; BELLO, J. (2002). Composition of pâtés elaborated with mackerel flesh (Scomber scombrus) and tuna liver (Thunnus thynnus): comparison with commercial fish pâtés. Food Chemistry, 77, 147-153.

ASSOCIATION OF OFFICIAL ANALYTICAL CHEMISTS (AOAC). Official methods of analysis. 18th ed. Washington, DC, 2000.

BARTHEM, R. B.; FABRÉ, N. N. Biologia e diversidade dos recursos pesqueiros da Amazônia. In: RUFFINO, M.L. (Org.) A pesca e os recursos pesqueiros na Amazônia brasileira. 4 ed. Manaus: Ibama/ProVárzea. p. 17-62, 2004.

BEGOSSI, A.; SALIVONCHYK, S. V.; HALlWASS, G.; HANAZAKI, N.; LOPES, P. F. M.; SILVANO, R. A. M.; DUMARESQ, D.; PITTOCK, J. (2019). Fish consumption on the Amazon: a review of biodiversity, hydropower and food security issues. Brazilian Journal of Biology, 79 (2), 345 357.

BRASIL. Decreto $n^{\circ} 9013$, de 29 de março de 2017. Regulamenta a Lei $n^{\circ} 1.283$, de 18 de dezembro de 1950, e a Lei ${ }^{\circ} 7.889$, de 23 de novembro de 1989, que dispõem sobre a inspeção industrial e sanitária de produtos de origem animal. Diário Oficial da União, Poder Executivo, Brasília, 2017. 
BRASIL. Ministério da Agricultura. Departamento de Inspeção de Produtos de Origem Animal. Regulamento Técnico de Identidade e Qualidade de Patê. 2000.

BRASIL. Ministério da Agricultura e do Abastecimento. Portaria n ${ }^{\circ} 1002$, de 11 de dezembro de 1998. Lista os produtos, comercializados no país, enquadrando-os nas Sub-categorias que fazem parte da Categoria 8 - Carnes e Produtos Cárneos. Diário Oficial da União, Poder Executivo, Brasília, 14 dez. 1998.

BRASIL. Ministério da Agricultura e do Abastecimento. Portaria no 1004, de 11 de dezembro de 1998. Aprova o Regulamento Técnico: "Atribuição de Função de Aditivos, Aditivos e seus Limites Máximos de uso para a Categoria 8 - Carne e Produtos Cárneos". Diário Oficial da União, Poder Executivo, Brasília, 14 dez. 1998.

BRASIL. Ministério da Pesca e Aquicultura (MPA). Semana do Peixe populariza consumo de pescado no País. 2014.

DORIA, C. R. C.; RUFFINO, M. L.; HIJAZI, N. C.; CRUZ, R. L. (2012). A pesca comercial na bacia do rio Madeira no estado de Rondônia, Amazônia brasileira. Acta Amazonica, 42 (1), 29-40.

ECHARTE, M.; CONCHILlO, A.; ANSORENA, D.; ASTIASARÁN, I. (2004). Evaluation of the nutritional aspects and cholesterol oxidation products of pork liver and fish pâtés. Food Chemistry, 86 (1), 47-53.

INFOPESCA. O mercado de pescado na região metropolitana de Manaus. [Manaus], 2010.

INSTITUTO ADOLFO LUTZ - IAL. Métodos Físico-químicos para Análise de Alimentos. 4. ed. São Paulo: IAL, 2008. 1020 p. Versão eletrônica.

ISAAC, V. J.; ALMEIDA, M. C.; CRUZ, R. E. A.; NUNES, L. G. (2015). Artisanal fisheries of the Xingu River basin in Brazilian Amazon. Brazilian Journal of Biology, 75 (3), 125-137.

MACHADO, N. D. J. B.; DA COSTA, T. V.; FRAGATA, N. P.; PEREIRA, C. V. L.; BRASIL, R. J. M.; BONATTO, E. C. S.; DE ANDRADE, E.G.; DE OLIVEIRA, R. P. M. (2020). Análise sensorial de filés de jaraqui/Sensory analysis of jaraqui fillets. Brazilian Journal of Development, 6 (5), 2936429376.

MINOZZO M. G. Elaboração de Patê cremoso a partir de Filé de Tilápia do Nilo (Oreochromis niloticus) e sua caracterização físico-química, microbiológica e sensorial. 2005. 127f. Dissertação (Mestrado em Tecnologia do Alimento) - Universidade Federal do Paraná, 2005.

MINOZZO, M, G.; WASZCZYNSKYJ, N.; BOSCOLO, W. R. (2008). The application of the Tilapia (Oreochromis niloticus) minced meat, in creamy and pasty pâtés. Alimentos e Nutrição Araraquara, 19 (3), 315-319.

OGAWA, M. Química do pescado: Umidade e Proteína. In: OGAWA, M.; MAIA, E. L. Manual de Pesca. Ciência e Tecnologia, São Paulo: Livraria Varela, v.1, cap. 4, p. 29-48, 1999.

PEREIRA, L. A.; FONSECA, V. V. (2011). Controle de qualidade de pescados com verificação dos seus pcc's em um restaurante no município de Volta Redonda. Interbio, 5 (1), 21-28. 
SALES, R. de O.; SALES, A. M. (1990). Estudo da composição química e rendimento de dez espécies de pescado de água doce de interesse comercial nos açudes do nordeste brasileiro. Ciências Agronômicas, 1/5 (21), 27-30.

SANTOS, G. M. D.; FERREIRA, E.J.G; ZUANON, J.A.S. (2006). Peixes comerciais de Manaus. Editora INPA.

SCHMELZER-NAGEL, W. (1999). Patê: Novos aspectos tecnológicos. Revista Nacional da carne, 267, 40-50.

SOUSA, D.N. (2014). Os estudos de extensão pesqueira nos Programas de Pós-Graduação em Extensão Rural. Extensão Rural, 21, 32-51.

VOSSEN, E.; EVELYNE, H. A.; DOOLAEGE, H.; DEMEWEZ, M.; BRUNO, M.; SLAWOMIR, S.; KATLEEN, R.; STEFAAN, S. (2012). Effect of sodium ascorbate dose on the shelf life stability of reduced nitrite liver pâtés. Meat Science, 91, 29-35. 